\title{
PEMBELAJARAN TWO STAY TWO STRAY UNTUK MENINGKATKAN KOMUNIKASI MATEMATIS PADA MATERI RELASI DAN FUNGSI DI SMP AL INAYAH PURWOSARI PASURUAN
}

\author{
Rosita Dwi Ferdiani \\ Dosen Pendidikan Matematika Universitas Kanjuruan Malang \\ Email: Rositazahra22@gmail.com
}

\begin{abstract}
Abstrak
Penelitian ini bertujuan untuk mendeskripsikan langkah -langkah pembelajaran Two Stay Two Stray yang meningkatkan komunikasi matematis pada materi relasi dan fungsi di kelas VIII SMP Al Inayah Purwosari. Jenis penelitian ini adalah penelitian tindakan kelas secara kolaboratif yang dilakukan untuk meningkatkan komunikasi siswa pada materi relasi dan fungsi. Penelitian ini termasuk penelitian tindakan kelas yang dilaksanakan dilaksanakan di SMP Al Inayah Purwosari, Pasuruan pada semester gasal. Subjek penelitian ini adalah siswa kelas VIII. Data dalam penelitian ini adalah hasil validasi perangkat pembelajaran dalam lembar validasi, skor siswa dalam mengerjakan tes, hasil observasi aktivitas guru dan siswa dalam lembar observasi, hasil wawancara terhadap 4 subjek penelitian, hasil catatan lapangan selama pembelajaran berlangsung. Hasil Penelitian berdasarkan hasil tes pertama terdapat 19 siswa yang memporelah nilai $\geq 65$ dan siswa yang memperoleh nilai $\leq 65$ sebanyak 9 siswa, dengan nilai tertinggi sebesar 90, nilai terendah sebesar 52 dan rata - rata kelas 74,10. Berdasarkan perolehan nilai hasil tes tersebut berarti ketuntasan klasikal adalah $71 \%$. Pada siklus II terjadi peningkatan komunikasi matematis siswa yang diikuti dengan peningkatana pemahaman siswa terbukti adanya peningkatan nilai rata - rata dari 74,10 menjadi 81,17 dan peningkatan ketuntasan klasikal sebesar 18, $28 \%$, yaitu dari $71 \%$ meningkat menjadi 89, $28 \%$.
\end{abstract}

Kata Kunci : pembelajaran two stay two stray, peningkatan komunikasi matematis, relasi dan fungsi

\begin{abstract}
This research aimed to describe the learning steps of Two Stay Two Stray to improve mathematical communication among 8th graders of Al Inayah Junior High School Purwosari Pasuruan . As a collaborative classroom action research, the purpose of this research was to increase students' communication while learning the subject of "relation and function". This action research were conducted in SMP Al Inayah Purwosari, Pasuruan, during odd semester. The research subjects were 8 th grade. The data in this study were gathered from validation of learning outcomes, students' test scores, observation of teacher \& students' activities, interviews with four research subjects, \& field notes during teaching $\&$ learning process. It was known from the result of the first tests that 19 students obtained scores $\geq 65$ and 9 students got $\leq 65$. The highest score was 90 , while the lowest score was 52 , and the average score was 74.10. Thus, it can be inferred that the classical completeness was $71 \%$. Later on, in the 2nd cycle, it was known that students' mathematical communication were increased. It was followed by the improvement of students' comprehension--as shown by the increasing average scores from 74.10 to 81.17 and the increasing classical completeness from $71 \%$ to $89.28 \%$.
\end{abstract}

Keywords: two stay two stray, improving mathematical communication, relation and function.

Pada era globalisasi saat ini tentunya diperlukan sumber daya manusia yang kreatif, inovatif, dan bermental tangguh dalam menghadapi semua tantangan yang ada. Sehingga peranan ilmu pengetahuan dan teknologi memegang peranan penting dalam perkembangan jaman modern ini. Ilmu - ilmu sains tentunya sangat berperan penting dalam perkembangan saat ini, salah satunya yaitu ilmu matematika.

Terkadang keterlibatan manusia akan matematika kurang dapat disadari oleh manusia itu sendiri. Hal ini disebabkan kurangnya komunikasi dalam menyampaikan peranan atau keterkaitan 
matematika dalam permasalahan sehari hari khususnya pada pembelajaran di kelas.

Salah satu akibat kegagalan pembelajaran adalah kurang adanya komunikasi antara guru dan siswa. komunikasi menjdi hal yang sangat penting dalam pembelajaran karena dengan adanya komunikasi terdapat kesamaan pandangan (konsep) antara siswa dan guru. Pembelajaran yang hanya berjalan satu arah (teacher center) mengakibatkan siswa tidak dapat mengembangkan kemampuannya dalam menyampaikan pendapat atau pemikiran siswa. Hal ini sejalan dengan pemikiran Baroody (1993: 107), bahwa pembelajaran harus dapat membantu siswa mengkomunikasikan ide matematika melalui lima aspek komunikasi yaitu (1) representing (membuat representasi berarti membuat bentuk yang lain dari ide atau permasalahan, misalkan suatu bentuk tabel direpresentasikan ke dalam bentuk diagram atau sebaiknya),(2) listening (aspek mendengar merupakan salah satu aspek yang sangat penting dalam diskusi. Kemampuan dalam mendengarkan topiktopik yang sedang didiskusikan akan berpengaruh pada kemampuan siswa dalam memberikan pendapat atau komentar),(3) reading (proses membaca merupakan kegiatan yang kompleks, karena di dalamnya terkait aspek mengingat, memahami, membandingkan, menganalisis, serta mengorganisasikan apa yang terkandung dalam bacaan), (4) discussing (salah satu bentuk komunikasi matematis adalah berbicara (speaking), hal ini identik dengan diskusi (discussing)) dan (5) writing (menulis tentang sesuatu yang dipikirkan dapat membantu para siswa untuk memperoleh kejelasan serta dapat mengungkapkan tingkat pemahaman para siswa tersebut).

Pemahaman matematis siswa mempunyai kaitan erat dengan komunikasi matematis siswa. Siswa yang sudah mempunyai pemahaman matematis akan dapat mengkomunikasikan kepada orang lain. Dengan mengkomunikasikan pemahaman matematisnya kepada orang lain maka pemahaman tersebut dapat ditingkatkan. Hal ini tentunya sejalan dengan pemikiran Greenes dan Schulman (1996: 168) yang menyatakan bahwa komunikasi matematik merupakan: (I) kekuatan utama bagi siswa dalam merumuskan konsep dan strategi matematik, (2) modal keberhasilan bagi siswa dalam menentukan pendekatan dan penyelesaian matematik, (3) tempat bagi siswa dalam berkomunikasi dengan siswa lainnya untuk memperoleh informasi, membagi pikiran dan penemuan, tukar pendapat pendapat, dan mempertajam ide untuk meyakinkan orang lain. Untuk itu pembelajaran dua arah antara guru dan siswa sangatlah penting untuk dilakukan guna melatih kemampuan komunikasi siswa.

Kurangnya

kemampuan komunikasi siswa dalam menyampaikan pendapat, ide, atau permasalahan matematika tercermin pada pembelajaran matematika di kelas 8 SMP Al Inayah Purwosari Pasuruan. Siswa kurang percaya diri dalam menjawab pertanyaan guru atau merasa malu malu dalam menyampaikan pendapatnya. Hal ini menunjukkan kurangnya aktifitas untuk melatih kemampuan komunikasi siswa. Berdasarkan wawancara dengan guru matematika kelas 8, kemampuan matematis siswa juga sangatlah kurang sehingga jumlah anak yang mencapai KKM pada semester ganjil hanya $45 \%$ dari 28 siswa dan dengan KKM sebesar 6.50 .

Prinsip dasar dalam kegiatan pembelajaran adalah berpusat pada siswa. Namun kenyataannya, kegiatan pembelajaran yang berlangsung hanya berpusat pada guru yaitu pembelajaran hanya difokuskan pada pemindahan 
pengetahuan kepada siswa, sehingga siswa kurang mendapatkan pengalaman belajar secara langsung yang mengakibatkan rendahnya kemampuan dalam berkomunikasi. Usaha yang dapat dilakukan guru untuk mencapai pembelajaran yang optimal, yaitu dengan memilih dan menerapkan model pembelajaran yang sesuai dan efektif, sehingga dapat menarik minat belajar siswa. Hal tersebut dapat diwujudkan dengan cara menerapkan model pembelajaran yang memberi kesempatan kepada siswa untuk berinteraksi, saling bertukar pikiran, mengaktifkan siswa dalam pembelajaran,saling berdiskusi antar siswa, bekerja sama dalam kelompok serta melibatkan dalam membuat kesimpulan.

Salah satu alternative untuk mendorong siswa dalam mengembangkan komunikasi dan berinteraksi dengan siswa lainnya adalah pemilihan metode cooperative learning. Metode pembelajaran cooperative learning banyak jenisnya, salah satu di antaranya model pembelajaran two stay two stray atau dua tinggal dua tamu. Metode cooperative learning model Two Stay Two Stray, adalah salah satu alternative untuk meningkatkan kemampuan komunikasi. Pembelajaran Two Stay Two Stray atau Dua Tinggal Dua Tamu diawali dengan pembagian kelompok. Setelah kelompok terbentuk, guru memberikan tugas berupa permasalahan-permasalahan yang harus mereka selesaikan, siswa yang tetap berada ditempat (stay) mempresentasikan hasil jawaban kepada kelompok yang bertamu (Suprijono, 2012). Menurut Isjoni (2007: 79) model cooperative learning tipe two stay two stray adalah teknik yang dikembangkan Spencer Kagan dan bisa digunakan dengan teknik kepala bernomor. Teknik ini memberi kesempatan kepada siswa untuk membagikan hasil informasi dengan kelompok lain. Pembelajaran menggunakan model cooperative learning tipe two stay two stray dapat meningkatkan komunikasi siswa. Tipe Two Stay Two Stray (TSTS) dalam pembelajaran diharapkan dapat meningkatkan komunikasi pada materi Relasi dan Fungsi di kelas VIII SMP AL Inayah Purwosari Pasuruan.

\section{Metode Penelitian}

Jenis penelitian ini adalah penelitian tindakan kelas secara kolaboratif yang dilakukan untuk meningkatkan komunikasi siswa pada materi relasi dan fungsi..Prosedur penelitian meliputi (1) perencanaan (planning), (2) pelaksanaan tindakan (action), observasi(obsevation), dan refleksi (reflection) dalam setiap siklus.

Penelitian ini dilaksankan di SMP Al Inayah Purwosari- Pasuruan yang berlokasi di jalan Masjid Kemantren, Dusun Kemantren, Desa Martupuro, Kec. Purwosari-Pasuruan pada semester gasal. Subjek penelitian ini adalah siswa kelas VIII dengan jumlah 28 siswa perempuan. Data dalam penelitian ini adalah hasil validasi perangkat pembelajaran dalam lembar validasi, skor siswa dalam mengerjakan tes, hasil observasi aktivitas guru dan siswa dalam lembar observasi, hasil wawancara terhadap 4 subjek penelitian, hasil catatan lapangan selama pembelajaran berlangsung.

\section{Hasil Penelitian dan Pembahasan Tahap Pra Pendahuluan}

Tahap awal penelitian dimulai dengan mengadakan pertemuan dengan kepala sekolah dan guru bidang studi matematika SMP Al -Inayah. Pemilihan materi tentang relasi dan fungsi berdasarkan hasil wawancara dengan guru matematika kelas VIII. Berdasarkan informasi yang diperoleh, materi yang dianggap sulit oleh siswa selama semester satu adalah materi tentang relasi dan fungsi. 


\section{Paparan Data Siklus I}

Perencanaan (planning)

Pada tahap perencanaan (planning), hal yang dilakukan adalah membuat skenario pembelajaran. Adapun rincian skenario pembelajaran nya adalah sebagai berikut:

1. Tahap Awal

Guru menyampaikan tujuan pembelajaran kemudian menggali pengetahuan awal siswa tentang relasi serta dilanjutakan dengan pemberian motivasi.

2. Tahap Inti

a) Guru memberikan contoh prosedur kerja tentang tahapan dalam Two Stay Two Stray

b) Meminta siswa untuk duduk bersama kelompoknya masing masing

c) Meminta sisa untuk berdiskusi dalam menyelesaikan soal di lembar kerja siswa. Tiap kelompok diberikan lembar kerja siswa yang berbeda - beda permasalahannya (soalnya)

d) Setelah siswa menerima lembar kegiatan yang berisi permasalahanpermasalahan yang berkaitan dengan konsep materi dan klasifikasinya, guru meminta siswa untuk untuk mendiskusikan masalah tersebut bersama anggota kelompoknya. Masing-masing kelompok memecahkan masalah yang diberikan dengan cara mereka sendiri. Kemudian 2 dari 4 anggota dari masing-masing kelompok meninggalkan kelompoknya dan bertamu ke kelompok yang lain, sementara 2 anggota yang tinggal dalam kelompok bertugas menyampaikan hasil kerja dan informasi mereka ke tamu. Setelah memperoleh informasi dari 2 anggota yang tinggal, tamu mohon diri dan kembali ke kelompok masing- masing dan melaporkan temuannya dan membahas hasilhasil kerja mereka

e) Meminta siswa mempresentasikan hasil jawaban kelompok siswa

f) Memberikan penguatan atau penegasan materi yang telah dipelajari.

g) Memberikan penguatan atau penegasan materi yang telah dipelajari.

h) Memberikan penghargaain kepada kelompok siswa yang mendapat skor tertinggi

\section{Tahap Akhir}

Membuat kesimpulan dan merumuskan hasil kerja kelompok.

\section{Pelaksanaan Tindakan}

Tahap tindakan merupakan penerapan dari tahap perencanaan. Peneliti melaksanakan tindakan sesuai dengan rencana yang telah disusun dalam rencana pelaksanaan pembelajaran. Pada tahapan ini, peneliti melaksanakan pembelajaran dengan menggunakan model Two Stay Two Stray. Pelaksanaan Kegiatan Pembelajaran dalam penelitian ini terbagi menjadi dua siklus. Tiap siklus terdapat tiga kali pertemuan. Pertemuan pertama membahas tentang Relasi, pertemuan kedua membahas tentang fungsi, sedangkan pertemuan ketiga membahas tentang penentuan nilai fungsi.

Berdasarkan hasil tes pertama terdapat 19 siswa yang memporelah nilai $\geq 65$ dan siswa yang memperoleh nilai $\leq$ 65 sebanyak 9 siswa, dengan nilai tertinggi sebesar 90, nilai terendah sebesar 52 dan rata - rata kelas 74,10. Berdasarkan perolehan nilai hasil tes tersebut berarti ketuntasan klasikal adalah $71 \%$.

\section{Hasil Observasi}

Pada saat pembelajaran berlangsung, peneliti dibantu oleh tiga orang pengamat yang selalu mengamati 
aktivitas siswa dan mencatatnya dalam lembar observasi kemandirian belajar siswa dan lembar observasi pelaksanaan pembelajaran

Tabel 1 Hasil Analisis Observasi Aktivitas Guru dan Siswa Pada Pertemuan Pertama

\begin{tabular}{ccc}
\hline Observer & Skor Aktivitas Guru & Skor Aktivitas \\
\hline I & $90 \%$ & $75 \%$ \\
\hline II & $95 \%$ & $75 \%$ \\
\hline
\end{tabular}

Tabel 2 Hasil Analisis Observasi Aktivitas Guru dan Siswa Pada Pertemuan Kedua

\begin{tabular}{ccc}
\hline Observer & Skor Aktivitas Guru & Skor Aktivitas Siswa \\
\hline I & $85 \%$ & $75 \%$ \\
\hline II & $90 \%$ & $80 \%$ \\
\hline
\end{tabular}

Tabel 3 Hasil Analisis Observasi Aktivitas Guru dan Siswa Pada Pertemuan Ketiga

\begin{tabular}{ccc}
\hline Observer & Skor Aktivitas Guru & Skor Aktivitas Siswa \\
\hline I & $90 \%$ & $80 \%$ \\
\hline II & $90 \%$ & $80 \%$ \\
\hline
\end{tabular}

$\quad$ Hasil $\begin{gathered}\text { observasi } \\ \text { dari ketiga } \\ \text { observer } \\ \text { terhadap }\end{gathered}$ pelaksanaan
pembelajaran dengan menggunakan
model Two Stay Two Stray menunjukkan
hasil yang sangat baik. Tetapi terdapat
tahapan yang direncanakan dalam RPP
tidak dilaksanakan oleh guru.

Berdasarkan hasil refleksi terdapat beberapa kendala selama pelaksanaan siklus 1 yaitu:

1. Diskusi kelompok belum berjalan dengan baik, karena dalam kelompok terdapat siswa yang diam dan tidak mau bekerja sehingga terlihat ada keributan kecil dalam kelompok. Terlihat beberapa siswa yang suka mengobrol dan bercanda. Hal ini disebabkan oleh keterbatasan guru dalam memberikan pengawasan terhadap seluruh kelompok.

2. Siswa masih belum terbiasa dengan pembelajaran model Two Stay Two Stray . siswa belum terbiasa untuk berkomunikasi tentang masalah matematika dengan siswa lain. Sehingga siswa masih dibimbing guru untuk mengemukakan pendapatnya.

3. Siswa masih tampak malu - malu mengemukakan pendapatnya atau bertanya kepada siswa lain pada saat bertamu ke kelompok lain sehingga membutuhkan waktu yang lama, pada akhirnya pembelajaran tidak selesai tepat waktu.

4. Masih terdapat 9 siswa mendapat nilai kurang dari 65 (dibawah KKM)

Berdasarkan hasil refleksi tersebut, penelitian perlu dilanjutkan ke siklus II dengan memperbaiki rencana pembelajaran. Adapun rencana tindakan yang akan dilaksanakan pada siklus II antara lain :

a) Guru memberikan penjelasan kembali tentang pembelajaran dengan menggunakan model Two Stay Two Stray. Hal ini dilakukan agar siswa tidak mengalami kesulitan pada saat pembelajaran berlangsung.

b) Merevisi Lembar Kerja Siswa pada siklus I yaitu dengan memperjelas petunjuk kerja LKS.

c) Melanjutkan kompetensi dasar materi membuat sketsa grafik fungsi aljabar sederhana pada sistem koordinat Cartesius

d) Mereview materi sebelum pelaksanaan tes akhir. 


\section{Paparan Data Siklus II}

Pelaksanaan tindakan pada siklus II terdiri dari 2 pertemuan. Dengan melanjutkan kompetensi dasar materi membuat sketsa grafik fungsi aljabar sederhana pada sistem koordinat Cartesius.

Berdasarkan hasil tes kedua terdapat 25 siswa yang memporelah nilai $\geq 65$ dan siswa yang memperoleh nilai $\leq 65$ sebanyak 4 siswa, dengan nilai tertinggi adalah 100, nilai terendah adalah 55 dan rata - rata kelas 81,17 . Berdasarkan perolehan nilai hasil tes tersebut berarti ketuntasan klasikal adalah 89,28\%.

Pada saat pembelajaran berlangsung, peneliti dibantu oleh tiga orang observer yang selalu mengamati aktivitas siswa dan mencatatnya dalam lembar observasi aktivitas siswa dan lembar observasi kegiatan guru. Berikut ini adalah hasil analisa observer pada saat tindakan II:

Tabel 4 Hasil Analisis Observasi Aktivitas Guru dan Siswa Pada Pertemuan Pertama

\begin{tabular}{ccc}
\hline Observer & Skor Aktivitas Guru & Skor Aktivitas \\
\hline I & $95 \%$ & $85 \%$ \\
\hline II & $95 \%$ & $85 \%$ \\
\hline
\end{tabular}

Tabel 5 Hasil Analisis Observasi Aktivitas Guru dan Siswa Pada Pertemuan Kedua

\begin{tabular}{ccc}
\hline Observer & Skor Aktivitas Guru & Skor Aktivitas \\
\hline I & $85 \%$ & $85 \%$ \\
\hline II & $90 \%$ & $90 \%$ \\
\hline III & $85 \%$ & $90 \%$ \\
\hline
\end{tabular}

Berdasarkan refleksi pada sat siklus II, diskusi kelompok pada siklus II mulai berjalan dengan baik, siswa mulai aktif dan bertukar pikiran dengan teman sekelompoknya. Komunikasi siswa sudah mulai lancar. Siswa yang tadinya pasif, sudah mulai berkomunikasi dengan siswa lain. Peningkatan komunikasi matematis siswa diikuti dengan peningkatana pemahaman siswa. Hal ini terbukti adanya peningkatan nilai rata - rata dari 74,10 menjadi 81,17 dan peningkatan ketuntasan klasikal sebesar $18,28 \%$, yaitu dari $71 \%$ meningkat menjadi $89,28 \%$

\section{Simpulan}

Pembelajaran Two Stay Two Stray
dapat meningkatkan komunikasi
matematis pada materi Relasi dan Fungsi
di SMP AL Inayah Purwosari Pasuruan.
Pembelajaran Two Stay Two Stray atau
Dua Tinggal Dua Tamu diawali dengan

pembagian kelompok. Setelah kelompok terbentuk, guru memberikan tugas berupa permasalahan-permasalahan yang harus mereka selesaikan, siswa yang tetap berada ditempat (stay) mempresentasikan hasil jawaban kepada kelompok yang bertamu. Pada saat kegiatan bertamu, siswa yang sudah mempunyai pemahaman matematis akan dapat mengkomunikasikan pemahamannya kepada orang lain. Dengan mengkomunikasikan pemahaman matematisnya kepada orang lain maka pemahaman tersebut dapat ditingkatkan. Peningkatan komunikasi matematis siswa yang diikuti dengan peningkatana pemahaman siswa terbukti adanya peningkatan nilai rata - rata dari 74,10 menjadi 81,17 dan peningkatan ketuntasan klasikal sebesar 18, $28 \%$, yaitu dari $71 \%$ meningkat menjadi $89,28 \%$ 


\section{Pustaka Rujukan}

Baroody. A.J. 1993. Problem Solving,

Reasoning, and Communicating. New

York: Macmillan Publishing.

Greenes, C. \& Schulman, L. (1996).

"Communication Processes in

Mathematical Explorations and

Investigations". In

P. C. Elliott and M. J. Kenney (Eds.). 1996 Yearbook. Communication in Mathematics. K-12 and Be.vond. USA: NCTM.

Isjoni. 2007. Cooperative Learning Efectifitas Pembelajaran Kelompok. Alfabeta. Bandung

Suprijono, A. (2012). Cooperative Learning Teori \& Aplikasi PAIKEM. Yogyakarta: Pustaka Pelajar 